\title{
Update and clinical utility of alcaftadine ophthalmic solution $0.25 \%$ in the treatment of allergic conjunctivitis
}

This article was published in the following Dove Press journal:

Clinical Ophthalmology

8 July 2015

Number of times this article has been viewed

\section{DeGaulle I Chigbu \\ Alissa M Coyne}

Pennsylvania College of Optometry Salus University, Elkins Park, PA, USA
Correspondence: DeGaulle I Chigbu Pennsylvania College of Optometry Salus University, 8360 Old York Road, Elkins Park, PA 19027, USA

Tel + I 215 99| 4790

Fax + I 215 99| 4794

Email dchigbu@salus.edu
Abstract: Allergic disorders of the ocular surface are primarily characterized as IgE- and/or T-lymphocyte-mediated disorders that affect the cornea, conjunctiva, and eyelid. Approximately $40 \%$ of individuals in the developed countries have allergic conjunctivitis, and as such, it is the most common form of ocular allergy. Seasonal allergic conjunctivitis is the most prevalent type of allergic conjunctivitis that impacts the quality of life of patients. This article reviews the pharmacology, pharmacodynamics, pharmacokinetics, clinical trials, clinical efficacy, and safety of alcaftadine. Histamine and the pathological mechanism of ocular allergy will be briefly reviewed with the intent of providing a background for the detailed discussion on the clinical utility of alcaftadine in allergic conjunctivitis. The Medline PubMed, Elsevier Science Direct, and Google Scholar databases were used to search for evidence-based literature on histamine and immunopathological mechanism of allergic conjunctivitis, as well as on pharmacology, pharmacodynamics, pharmacokinetics, clinical trials, and clinical efficacy of alcaftadine. The treatment and management goals of allergic conjunctivitis are to prevent or minimize the inflammatory cascade associated with allergic response in the early stages of the pathological mechanism. It is of note that activation of histamine receptors on immune and nonimmune cells are associated with allergen-induced inflammation of the conjunctiva and its associated ocular allergic manifestations, including itching, edema, hyperemia, and tearing. Alcaftadine is an efficacious multiple action antiallergic therapeutic agent with inverse agonist activity on $\mathrm{H} 1$, $\mathrm{H} 2$, and $\mathrm{H} 4$ receptors, as well as anti-inflammatory and mast cell stabilizing effects that could provide therapeutic benefits to patients with allergic conjunctivitis.

Keywords: alcaftadine, allergic conjunctivitis, histamine, immunopathological mechanisms, ocular allergies

\section{Introduction}

Allergic disorders of the ocular surface are primarily characterized as IgE-medicated and/or T-lymphocyte-mediated disorders that affect the ocular surface, including the cornea, conjunctiva, and eyelid. ${ }^{1,2}$ Ocular allergies are usually categorized into acute or chronic allergic disorders based on their pathological mechanism and clinical expression of the allergic response on the ocular surface. ${ }^{3,4}$ The acute form includes seasonal allergic conjunctivitis (SAC) and perennial allergic conjunctivitis (PAC). Chronic forms are vernal keratoconjunctivitis (VKC) and atopic keratoconjunctivitis.

Allergic conjunctivitis is the most prevalent form of ocular allergy. It is predominantly an IgE-mediated ocular allergy that occurs when airborne allergens induce allergic expression on the ocular surface. ${ }^{5,6} \mathrm{SAC}$ is a seasonal variant of allergic conjunctivitis due to outdoor aeroallergens, whereas $\mathrm{PAC}$ is the perennial variant of allergic 
conjunctivitis due to indoor airborne allergens. ${ }^{5}$ Pollen is the major aeroallergen that is associated with SAC with increased incidence of SAC from tree pollen and grass pollen in the spring and summer months, respectively. Dust mites, pet dander, feathers, and mold are aeroallergens associated with PAC. ${ }^{2,7}$ Patients with allergic conjunctivitis may complain of ocular pruritus and redness following exposure to outdoor and indoor aeroallergens. ${ }^{8}$ Approximately $40 \%$ of individuals in the developed countries have allergic conjunctivitis. ${ }^{9}$ In the United States, allergic conjunctivitis is the most common form of ocular allergy that constitutes over $90 \%$ of all ocular allergies. ${ }^{2}$ Allergic conjunctivitis affects the ocular surface impacting the quality of life of patients. It affects the school performance of symptomatic students and work productivity through lost workman days. 5,9

The treatment and management goals of allergic conjunctivitis are to prevent or minimize the inflammatory cascade associated with allergic response in the early stages of the pathological mechanism. ${ }^{3}$ The magnitude of the allergic expression is dependent on the allergen load, allergic mediators expressed by immune and nonimmune cells, and other physiological factors. ${ }^{10}$ Histamine, leukotrienes, cytokines, chemokines, prostaglandins, and proteases are produced by activated mast cells in allergen-induced conjunctival inflammation in SAC and PAC. ${ }^{9}$ This article reviews the chemical compound, including pharmacology, pharmacodynamics, pharmacokinetics, clinical trials, clinical efficacy, and safety, of alcaftadine. The pathological mechanism of ocular allergy, histamine, and histamine receptors will be briefly reviewed with the intent of providing a background for the detailed discussion on the clinical utility of alcaftadine.

\section{Conjunctiva}

The conjunctivae are highly vascularized and immunologically active semitransparent mucous membranes that line the globe. ${ }^{4,11}$ The conjunctiva consists of two layers - epithelium and the substantia propria (conjunctival stroma). The conjunctival epithelium is a nonkeratinized mucosal tissue with mucin-secreting goblet cells and intraepithelial leukocytes. ${ }^{11,12}$ The substantia propria is composed of vascular connective tissue with lymphatics, immune cells, and nonimmune cells. ${ }^{12,13}$ The normal conjunctiva has neutrophils and intraepithelial lymphocytes in the epithelium and the substantia propria. However, macrophages and mast cells are present in the substantia propria but absent in the normal conjunctival epithelium. Eosinophils are not normally found in either the epithelium or the substantia propria. ${ }^{11,12,14-16}$ The conjunctiva has an abundance of Langerhans' cells that initiate allergen-induced immune response when these antigenpresenting cells encounter an allergen on the conjunctiva. ${ }^{11}$ The immune cells, such as lymphocytes, distributed over the conjunctiva form a mucosal immune system known as the conjunctiva-associated lymphoid tissue. ${ }^{17-19}$ Conjunctivaassociated lymphoid tissue is a component of the eyeassociated lymphoid tissue. It is of note that eye-associated lymphoid tissue consists of organized lymphoid tissue made up of predominantly lymphocytes. ${ }^{17,20,21}$ In normal conjunctiva, the mast cells are concentrated in the substantia propria. Immunohistochemical staining is the basis for characterizing the human mast cell as either tryptase containing (mucosal mast cell) or tryptase/chymase containing (connective type mast cell). ${ }^{1,22}$ Toll-like receptors (TLRs) are pattern-recognition receptors of the innate immune system that recognize exogenous and endogenous molecules. ${ }^{23}$ TLRs are expressed on both nonimmune (epithelial, endothelial cells, fibroblasts) and immune cells (macrophages, dendritic cells [DCs], lymphocytes, mast cells, neutrophils, and eosinophils). ${ }^{23,24}$ TLRs are known to play a role in initiating a signaling cascade that culminate in the generation of proinflammatory cytokines, chemokines, and adhesion molecules. ${ }^{13}$ Therefore, TLRs play a vital role in the ocular surface immune response, ${ }^{20}$ and the expression of TLRs in the conjunctival epithelium is increased during ocular allergic conditions. ${ }^{25}$ Additionally, the conjunctiva expresses transient receptor potential (TRP) channels that play a role in the pathophysiology of many diseases, including immune-mediated diseases. ${ }^{26}$ TRPV1 is a TRP channel expressed on definitive sensory nerves, epithelial cells, and mast cells, and activation of TRPV1 is associated with histamine-induced pruritus. ${ }^{27}$ The healthy conjunctiva has intercellular tight junction proteins that help maintain the barrier function of the conjunctival epithelium, a barrier that is impermeable to allergens. ${ }^{28}$ The occludin and claudin transmembrane protein complexes are major constituents of tight junction proteins that play a role in maintaining the stability and adhesion of epithelial cells on the ocular surface. Thus, changes to the epithelial barrier function are likely to play a role in the pathogenesis of allergic conjunctivis. ${ }^{10}$

\section{Histamine}

Histamine (2-(1H-imidazol-4-yl)ethylamine, $\beta$-aminoethylimidazole), a low molecular weight biogenic amine, is produced by L-histidine decarboxylate-mediated decarboxylation of histidine. ${ }^{29-31}$ Histamine produced following mast cell degranulation is degraded by histamine $N$-methyl transferase (HNMT) and diamine oxidase. ${ }^{32}$ It plays an important role in the pathomechanisms of allergen-induced 
conjunctival inflammation via activation of the G proteincoupled receptors. It is of note that histamine receptors are $\mathrm{G}$ protein-coupled receptors. ${ }^{30,33}$ Histamine also plays a role in a variety of other pathological processes. Although histamine is mainly produced by mast cells and basophils, other immune cells such as neutrophils and macrophages are capable of producing histamine. ${ }^{29}$ The genes encoding histamine type 1 (H1) and type 2 (H2) receptors are located on chromosomes 3 and 5, respectively. Genes located on chromosomes 20 and 18 encode histamine type 3 (H3) and 4 (H4) receptors, respectively. ${ }^{30} \mathrm{H} 1$ receptors are expressed on nerve cells, vascular smooth muscles, endothelial cells, epithelial cells, neutrophils, eosinophils, monocytes, macrophages, DCs, T-cells, and B-cells. ${ }^{34,35} \mathrm{H} 2$ receptors are expressed on nerve cells, vascular smooth muscles, endothelial cells, epithelial cells, neutrophils, eosinophils, macrophages, monocytes, DCs, T-cells, and B-cells. ${ }^{34,36} \mathrm{H} 3$ receptors are usually expressed on nerve cells and goblet cells. It is of note that histamine receptors 1,2 , and 4 are also expressed on goblet cells of the conjunctiva. ${ }^{13}$ Histamine induces itching via activation of $\mathrm{H} 1$ receptors expressed on sensory nerve fibers in the conjunctiva, and histamine-induced itching requires activation of TRPV $1 .{ }^{37} \mathrm{H} 1$ and $\mathrm{H} 2$ receptors mediate vasodilation and increased permeability of conjunctival vessels that occur in response to allergen-induced inflammatory response. ${ }^{2,35}$ The vasodilation and increased vasopermeability of the conjunctival vessels manifests as conjunctival hyperemia and chemosis, respectively. H4 receptors are involved in inflammation, allergy, and immunomodulation. These receptors are expressed on mast cells, basophils, eosinophils, monoctyes, macrophages, T-cells, basophils, and DCs. ${ }^{31,35} \mathrm{H} 4$ receptors mediate the recruitment of mast cells, eosinophils, and T-lymphocytes to the site of allergen-induced inflammation. ${ }^{35,38}$ This further amplifies the histamine-mediated immunopathological response in the conjunctiva. ${ }^{33}$ In ocular allergy, histamine binding to $\mathrm{H} 4$ receptors on eosinophils primes eosinophils to respond to eotaxin, a chemokine for eosinophils. ${ }^{31}$

\section{Immunopathological mechanisms}

Exposure of the conjunctiva to allergens is associated with an immunopathological response that occurs in three phases sensitization, early phase, and late phase.

\section{Sensitization phase}

The sensitization phase of allergic conjunctivitis occurs on initial exposure of the conjunctiva to airborne allergens such as pollen. When the allergens are deposited on the conjunctiva, the allergen via action of their proteolytic enzymes degrade the tight junction of the conjunctiva epithelial cells in order to gain access to immune cells such as macrophages, DCs, and mast cells. The immature DCs will engulf the allergen, process it, and undergo biochemical changes that lead to the upregulation of major histocompatibility complex (MHC) class II molecules. The processed allergen is displayed as a peptide in association with MHC class II molecules on the DCs. The mature DC will migrate to the regional lymph node where they activate naïve T-cells to proliferate and differentiate into Th2-lymphocytes. ${ }^{39}$ The Th2-lymphocytes secrete cytokines such as IL-4, IL-5, and IL-13. ${ }^{5,13}$ Additionally, the naïve B-lymphocyte interacts with the same allergen, processing the allergen into peptides that are presented in association with MHC class II molecules as a peptide:MHC class II complex on the B-cell receptors. Interaction between T-cell receptors of the allergen-specific Th2-lymphocytes and B-cell receptors of the allergen-activated B-lymphocytes in conjunction with CD40-CD40L interactions in the presence of IL-4 will trigger the proliferation and differentiation of the B-lymphocyte into IgE-secreting plasma cells. ${ }^{40,41}$ Additionally, allergens in contact with the conjunctiva can trigger conjunctival epithelial cells to produce thymic stromal lymphopoietin (TSLP), which in turn activates DCs through TSLP-TSLPR receptor interaction to induce the activation of naïve T-cells via OX40L-OX40 signaling pathways ${ }^{42,43}$ and their subsequent differentiation into Th2 cells that produce IL-4 that induce B-cells to produce IgE-secreting plasma cells. ${ }^{44}$ TSLP is capable of causing ocular itch via activation of TSLP receptors on sensory neurons and/ or immune cells that release mediators that interact with their respective sensory receptors. ${ }^{45}$ Thus, TSLP also participates in the initiation of the sensitization process and the exacerbation of allergic eye diseases. ${ }^{43}$ The allergen-specific IgE traffics to the mast cells in the conjunctiva and binds to high-affinity IgE receptors (FceRI) located on the surface of mast cells. The mast cells with FceRI bound to IgE become primed mast cells that will undergo activation and degranulation upon subsequent exposure to allergens. ${ }^{1,39,41}$

\section{Early phase response}

An allergic reaction will be initiated when previously sensitized eyes are re-exposed to the allergen. The allergens activate Th2-lymphocytes to secrete Th2-lymphocyte-derived cytokines. ${ }^{46}$ This binding of multivalent allergens to $\operatorname{IgE}$ molecules on FceRI induces cross-linking of the IgE-FceRI complex on the primed mast cells, which in turn activates the primed mast cell to undergo degranulation. Degranulation of the mast cells leads to three immunobiological responses 
that are characterized by the release of preformed mediators such as biogenic amines (eg, histamine) and neutral proteases (eg, tryptase), synthesis and release of lipid mediators (eg, prostaglandin), and production and release of cytokines (eg, IL-4). This is the activation phase of allergic response of allergic conjunctivitis. ${ }^{5,39}$ It is noteworthy that the early-phase response occurs within 3-5 minutes of allergen exposure, and it usually lasts for less than an hour. ${ }^{39,47}$

Histamine binding to receptors on the ocular surface is associated with altered permeability of epithelium that disrupts the epithelial barrier function of the conjunctiva. It also stimulates epithelial cells of the conjunctiva to release adhesion molecules, chemokines, and proinflammatory cytokines. ${ }^{48}$ The interaction of histamine with histamine receptors expressed on immature DCs recruits and activates DCs to become mature antigen-presenting cells capable of activating naïve $\mathrm{T}$ lymphocytes to become activated CD4 T lymphocytes that subsequently differentiate into Th2lymphocytes. ${ }^{29,32,36}$ Thus, Th2-lymphocytes along with mast cells are the major immune cells involved in allergic inflammatory response in allergic conjunctivitis. ${ }^{4}$ The binding of released histamine from degranulated mast cells to histamine receptors on vascular endothelial cells, neuronal fibers, goblet cells, immune cells, and conjunctival epithelium culminates in the clinical manifestation of allergic conjunctivitis (redness, itching, tearing, chemosis, and eyelid edema). ${ }^{13}$ Furthermore, the interaction of histamine with histamine receptors on conjunctival goblet cells and nerve fibers causes increased mucus secretion and itching in allergic conjunctivitis, respectively. ${ }^{2}$ Tryptase released following mast cell degranulation induces the proliferation of conjunctival fibroblasts, as well as potentiates the effect of histamine. It is of note that tryptase and histamine are considered biomarkers of allergen-induced IgE-mediated conjunctival allergic response. ${ }^{5}$

\section{Late phase response}

The late-phase response occurs 2-4 hours following the early-phase response, and it could last for many hours. ${ }^{13}$ The late phase of allergic conjunctivitis is mediated by lipid mediators (prostaglandins and leukotrienes) formed from products of arachidonic acids oxidative metabolism and cytokines that recruit and activate inflammatory cells such as eosinophils, lymphocytes, monocytes, and neutrophils. ${ }^{39}$ Mast cell degranulation is associated with the release of cytokines (IL-4, IL-5, IL-6, IL-13, TNF- $\alpha$, and TGF- $\beta$ ), growth factors, and chemokines (CXCL8, CCL3, CCL5, and eotaxin). Cytokines activate conjunctival epithelial cells and fibroblasts to express chemokines and adhesion molecules. Chemokines and adhesion molecules mediate the recruitment of eosinophils and other inflammatory cells to the site of allergic inflammation. ${ }^{9,22,49}$ These mediators recruit inflammatory cells such as lymphocytes, eosinophils, and neutrophils into the conjunctiva. ${ }^{9}$ Prostaglandins (eg, PGD2) cause conjunctival hyperemia by inducing vasodilation as well as intensify the histamine-mediated pruritus. Additionally, leukotriene B4 can activate TRPV1 and induce itching via interaction with LTB4 receptors on sensory nerves. ${ }^{50}$ Leukotriene (LTC4 and LTD4) can induce vasodilation and vascular leakage that leads to efflux of fluid from the conjunctival vessels into the mucosal tissue (causing conjunctival edema) and inducing goblet cells to produce excessive amounts of mucus. Thus, leukotrienes augment the vasodilation and increased vascular permeability effects of histamine., ${ }^{2,5,39}$ The lipid mediators play a major role in allergen-induced conjunctival inflammation in the early stages of the late-phase response of activation phase of allergic conjunctivitis. Cytokines and chemokines released following mast cell degranulation are involved in cellular infiltration of the conjunctiva. IL-4 released induces the generation of IgE-producing plasma cells, expression of adhesion molecules, induces conjunctival fibroblasts to release eotaxin and differentiation of activated CD4 T-cells into Th2 cells. IL-5 and eotaxin are involved in the activation and recruitment of eosinophils to the site of allergen-induced conjunctivitis. ${ }^{2}$ Eosinophils that are recruited to the conjunctiva undergo degranulation to release cationic granule proteins, eosinophil-derived enzymes, lipid mediators, chemokines, and cytokines. ${ }^{1}$ Additionally, activated eosinophils degranulate to release granule contents that are epitheliotoxic to the conjunctival epithelium that could further compromise the integrity of the epithelial barrier function. ${ }^{10}$ Other cells recruited during the late phase include lymphocytes, neutrophils, and monocytes. The cells recruited and activated during the late phase of the response cause inflammation and tissue remodeling. ${ }^{39,51}$ Adhesion molecules, such as vascular cell adhesion molecule and intercellular adhesion molecule, play a role in recruitment and transmigration of inflammatory cells, including eosinophils and lymphocytes, into the conjunctiva leading to persistence of the chronic inflammatory reaction in the late phase of the allergen-induced conjunctival inflammation. ${ }^{2}$ Thus, the mast cell-derived cytokines and chemokines, as well as the lipid mediators, contribute to the development of the late-phase allergic inflammatory reaction and sustained inflammation at the site of the allergic reaction. ${ }^{1}$

\section{Alcaftadine}

Alcaftadine is an antiallergic therapeutic agent that has inverse agonist effects on $\mathrm{H} 1, \mathrm{H} 2$, and $\mathrm{H} 4$ receptors, as well 
as mast cell-stabilizing effects. In doing so, antihistaminic effect provides relief from itching associated with early phase of ocular allergic response, whereas mast cell stabilization inhibits the release of mediators such as cytokines and lipid mediators that play a role in late-phase response of allergic conjunctivitis. ${ }^{2,52,53}$

\section{Chemical structure of alcaftadine}

As shown in Figure 1, alcaftadine is a tricyclic piperidine aldehyde structure that is converted to a carboxylic acid metabolite in vivo. Its empirical formula and chemical name are $\mathrm{C}_{19} \mathrm{H}_{21} \mathrm{~N}_{3} \mathrm{O}$ and 6,11-dihydro-11-(1-methyl-4piperidinylidene)-5H-imidazo[2,1-b][3]benzazepine-3carboxaldehyde (CAS No 147084-10-4), respectively. ${ }^{54,55}$

Alcaftadine has a high affinity for the $\mathrm{H} 1$ and $\mathrm{H} 2$ histamine receptors measured in the nanometer range utilizing receptor binding studies. The compound also possesses a moderate affinity for the newly identified $\mathrm{H} 4$ receptor in the micrometer range. Moderate affinity was demonstrated in cholinergic muscarinic receptors in rat striatum. Other receptors with lower affinity included the human alpha2A adrenergic receptors, human serotonin 5HT1A, and human melanocortin MC4 receptors. Ligand displacement experiments found that alcaftadine did not interact with any other receptor, transporter, or ion channel binding site. These findings revealed that alcaftadine is an effective and specific ligand for $\mathrm{H} 1$ and $\mathrm{H} 2$ receptors. ${ }^{55}$

Preliminary studies of oral formulations of alcaftadine led to the discovery of its carboxylic acid metabolite. The latter compound demonstrated strong antihistamine activity during in vivo assays. Due to its bioactivity, further in vitro studies utilizing human liver microsomes and diagnostic cytochrome P450 (CYP450) substrates were performed to provide additional data regarding the metabolism of alcaftadine and its metabolite. Results showed that alcaftadine is metabolized via aldehyde oxidation to form the active carboxylic acid metabolite. Findings suggested that metabolism predominantly occurred via non-CYP450 enzymes and most likely involved soluble cystolic enzymes, aldehyde dehydrogenase, and aldehyde reductase. ${ }^{55}$ Neither alcaftadine nor its active metabolite substantially inhibited CYP450 enzymes. The lack of inhibition thereby indicated that no clinically relevant drug interactions associated with alcaftadine or its metabolite. ${ }^{56,57}$ It is of note that alcaftadine metabolism was inhibited by $25 \%-33 \%$ in the presence of erythromycin, loratadine, and ketotifen at in vitro concentrations five to eight times the therapeutic plasma concentration. ${ }^{55}$

Additionally, human plasma protein binding and red blood cell distribution were assessed. Drug distribution of alcaftadine exhibited that it has an affinity for red blood cells (39.17\% $\pm 1.4 \mathrm{SD})$, whereas the carboxylic acid metabolite is predominantly found in the plasma $(69.7 \% \pm 1.4 \mathrm{SD})$. Alcaftadine $0.25 \%$ ocular administration showed similar results to oral dosing with both modes of administration having low bioavailability. Peak plasma levels of ocular alcaftadine and its metabolite were reached at 15 minutes and 1 hour, respectively. ${ }^{55,58}$ Furthermore, concentration in plasma falls below detectable levels at 3 hours and 12 hours, respectively. Elimination of ocular alcaftadine $0.25 \%$ is primarily accomplished through cystolic enzyme-assisted metabolism to its metabolite. The acid metabolite is excreted unchanged in the urine. ${ }^{59}$ Systemic accumulation was not exhibited by alcaftadine or the carboxylic acid metabolite after multiple ocular dosing. ${ }^{55,58,59}$

\section{Clinical studies}

Eleven clinical studies were submitted as part of the FDA approval application for alcaftadine $0.25 \%$, including three randomized, double-masked, placebo-controlled studies. Additionally, published clinical studies have displayed the clinical efficacy and safety of the drop. Each published study utilized the conjunctival allergen challenge (CAC) model.
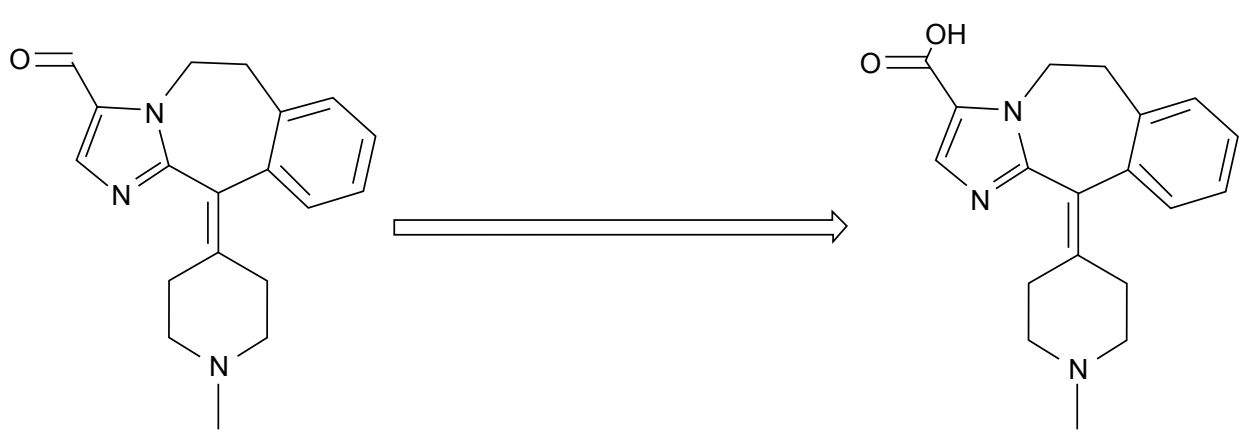

Figure I The chemical structure of alcaftadine and its primary metabolite.

Notes: The aldehyde structure is converted to a carboxylic acid to form the metabolite via aldehyde oxidation. Copyright (c) 20II, Mary Ann Liebert, Inc. This figure is reproduced with permission from Mary Ann Liebert, Inc. Reproduced from Bohets H, McGowan C, Mannens G, Schroeder N, Edwards-Swanson K, Shapiro A. Clinical pharmacology of alcaftadine, a novel antihistamine for the prevention of allergic conjunctivitis. Journal of Ocular Pharmacology and Therapeutics. 20I I;27(2): 187-I95. ${ }^{55}$ 
The CAC model is a well-utilized study design to evaluate antiallergy medications in a controlled environment. ${ }^{60}$ The CAC has been employed as a study model for over 20 years and utilized as a standard clinical method by the FDA in evaluating allergic diseases. ${ }^{28,61}$ The typical CAC format includes two baseline visits. The first visit allows the investigators to titrate the allergen dose in order to achieve the desired clinical response. The second visit then confirms the initial titration results. The patients who demonstrate reproducible results and the desired clinical response proceed to a third visit. During the third and fourth visits of the study, the onset and duration of action are measured by administering the medication (active ingredient) and comparative agents (placebo and comparator) followed by challenging the patient with the appropriate dose of allergen. ${ }^{58,60}$ Ocular allergy manifestations including hyperemia, chemosis, and pruritus are then evaluated. The patient rates the itch symptoms on a scale from 0 (least symptomatic) to 4 (most symptomatic). Study personnel utilize the same scale to rate ocular redness and chemosis signs of allergic conjunctivitis. The onset can be measured within minutes after drug instillation and the allergen challenge. The duration of action is measured at a separate visit whereby the allergen challenge is initiated at a specific time, usually hours after the medication has been administered..$^{58,60}$

\section{Clinical studies: alcaftadine and placebo}

Torkildsen and Shedden conducted a two-arm, doublemasked, multicenter, placebo-controlled Phase III study evaluating the safety and clinical efficacy of alcaftadine $0.25 \%$. Subject inclusion criteria were a history of ocular allergies with at least one positive skin test reaction to cat hair, cat dander, grasses, ragweed, dog dander, cockroach, dust mite, Japanese cedar, and/or tree pollen within the past 2 years, best-corrected visual acuity 0.6 logMAR or better in each eye using an Early Treatment of Diabetic Retinopathy Study chart, and a positive bilateral CAC reaction within 10 minutes of the last titration of allergen during the first visit. A positive bilateral reaction was determined to be $\geq 2$ units for the itching score and $\geq 2$ units for the redness score in two of the three vessel beds (conjunctival, episcleral, ciliary). Subjects progressed to future visits only if a positive bilateral CAC reaction was noted for at least two of the three time points during visit 2. Female subjects were required to have a negative urine pregnancy test and an approved form of birth control during the study. Fifty-eight subjects $\geq 10$ years of age with a reproducible, positive reaction to a CAC were randomized -29 patients received $0.25 \%$ alcaftadine and 29 patients received the placebo vehicle. The study consisted of four visits $\sim 5$ weeks. ${ }^{28}$
The primary endpoints of the study were ocular itching at 3 minutes, 5 minutes, and 7 minutes and conjunctival redness at 7 minutes, 15 minutes, and 20 minutes following allergen challenge. Subjects were asked to provide a numerical rating regarding itching at each time point on a scale of $0-4$, with half increments allowed. A score of 0 indicated no itching, whereas 4 indicated "an incapacitating itch with an irresistible urge to rub." An investigator scored conjunctival redness via slit lamp examination. Again, a scale of 0-4 with half increments was utilized where $0=$ none and $4=$ extremely severe described as "large, numerous, dilated blood vessels characterized by unusually severe deep red color, regardless of grade of chemosis, which involves the entire vessel bed." ${ }^{28,61}$

The secondary endpoints were all other signs and symptoms of allergic conjunctivitis. Findings were assessed at 7 minutes, 15 minutes, and 20 minutes by the investigator at visits 3 and 4 . Secondary findings included ciliary and episcleral redness, chemosis, lid swelling, tearing, ocular mucous discharge, nasal symptoms (rhinorrhea, nasal congestion, nasal pruritus, and ear or palate pruritus), and nasal symptom composite scores. Most secondary signs or symptoms were graded on a scale of $0-4$ with the exception of lid swelling (0-3 score), tearing (absent or present), and ocular mucous discharge (absent or present). ${ }^{28}$

Clinical efficacy was predefined as alcaftadine $0.25 \%$ showing clinical superiority over the vehicle by at least 0.5 units on the $0-4$ scale for all parameters and at least 1 unit advantage for at least two of three time points for ocular itching and conjunctival redness. ${ }^{27}$ A statistically significant $(P<0.001)$, clinically relevant difference of $>1$ unit in mean ocular itching score was measured in the alcaftadine group when compared to the vehicle placebo group at all time points following the CAC at 15 minutes and 16 hours. Mean conjunctival redness was statistically significantly lower $(P<0.05)$ in the alcaftadine group at 7 minutes, 15 minutes, and 20 minutes post-CAC. However, the change was not considered to be clinically significant as outlined in the predefined criteria as set forth by the FDA. Secondary endpoints data demonstrated statistically significant differences in the alcaftadine group compared to the vehicle in measured scores of mean ciliary redness (also clinically significant at 7 minutes post-CAC), episcleral redness, chemosis, lid swelling, tearing, rhinorrhea, and nasal congestion. ${ }^{28}$

Alcaftadine $0.25 \%$ exhibited a rapid onset and a prolonged duration of action throughout this study. Interestingly, the longest duration of time was measured at 16 hours, and the therapeutic effect had not diminished in that time frame, 
thereby suggesting that alcaftadine $0.25 \%$ may have a longer duration of action than evaluated. The treatment group demonstrated clinically significant improvement in ocular itching at every time frame. Statistical improvement but not clinically significant improvement was noted with conjunctival redness when comparing the treatment group to the placebo group. Secondary ocular and nasal symptoms were also relieved in the alcaftadine group. Alcaftadine $0.25 \%$ was also safely administered to patients in the study. Adverse effects were reported higher among the vehicle placebo group than the alcaftadine-treated group. ${ }^{28}$

Clinical studies: alcafatadine $0.05 \%, 0.1 \%$, and $0.25 \%$; olopatadine $0.1 \%$; and placebo

Greiner et al conducted a prospective, single-center, doublemasked, randomized, active-, and placebo-controlled CAC study. ${ }^{52}$ Four visits over 5 weeks utilizing the CAC model comprised the intent-to-treat analysis. The efficacy of three alcaftadine concentrations $(0.05 \%, 0.1 \%, 0.25 \%)$ was compared with a vehicle placebo and olopatadine hydrochloride ophthalmic solution $0.1 \%$ active control in order to determine relief of signs and symptoms of allergic conjunctivitis. Subject inclusion criteria were 18 years of age or older, history of ocular allergies and/or a positive skin test reaction to specified allergens within the past 24 months, best-corrected visual acuity 0.6 logMAR or better in each eye using an Early Treatment of Diabetic Retinopathy Study chart, and no contact lenses worn for at least 3 days prior to and during the study. Female participants were required to have a negative pregnancy test at the entrance and exit visit. The same criteria used to determine a positive bilateral reaction in the Torkildsen and Shedden study was utilized. ${ }^{28}$ Subjects progressed to future visits only if a positive bilateral CAC reaction was observed in at least two of the three time points. Reproducibility of titrated results at visit 2 was imperative to continue as a subject in the study. One hundred seventy subjects were equally randomized into five groups: placebo, alcaftadine $0.05 \%, 0.1 \%$, or $0.25 \%$, or the active control (olopatadine hydrochloride $0.1 \%$ ). One hundred sixty-four subjects completed the study. ${ }^{52}$

Duration of action was assessed at visit 3 by performing a CAC 16 hours after instillation of medication. Onset of action was evaluated at visit 4 whereby a CAC was performed 15 minutes after medication administration. ${ }^{52}$ The primary and secondary endpoints as well as the grading criteria were identical to those of the Torkildsen and Shedden study. ${ }^{28,52}$

Clinical efficacy for onset of action was predefined as $\geq 1$ unit difference and statistically significant with a
$P$-value $<0.001$ in assessing the prevention of itching. All active treatment groups, three alcaftadine concentrations and olopatadine $0.1 \%$, were clinically and statistically superior to the vehicle placebo at all time points. Conjunctival redness scores achieved statistical significance for all active treatment groups at every postchallenge time point. Each concentration of alcaftadine and olopatadine was statistically significant in preventing redness at the 7-minute assessment after the first allergy challenge. Furthermore, alcaftadine $0.25 \%$ and olopatadine $0.1 \%$ achieved statistical significance at the 15 -minute and 20-minute assessment post-CAC. Clinical significance ( $\geq 1$ unit difference) for reducing conjunctival redness was reached when comparing the mean scores for alcaftadine $0.25 \%$ and olopatadine $0.1 \%$ to those of the vehicle placebo at the 7 -minute time frame. ${ }^{52}$

Duration of action assessment at 16 hours indicated that all three alcaftadine concentrations produced lower mean ocular itching scores when compared to olopatadine $0.1 \%$ and the vehicle placebo. All active treatment groups had clinically and statistically significant scores than placebo at almost all time points except for olopatadine at 7 minutes. At 7-minute post-CAC, the difference in the prevention of itching was statistically significant for alcaftadine $0.25 \%$ versus olopatadine $(P=0.017)$. A different $P$-value was utilized when comparing a particular dose level if both primary endpoints were significant at the alpha (two-sided) $1.7 \%$ $(P=0.017)$ level. Mean conjunctival redness scores were also lower for all active treatment groups compared with placebo at CAC 16 hours after instillation of medication. Alcaftadine $0.25 \%$ and olopatadine $0.1 \%$ had statistically significant lower scores at all postchallenge time intervals. Only alcaftadine $0.25 \%$ showed clinically significant lower scores when compared to the placebo ( $\geq 1$ unit difference) at 7-minute and 15-minute post-CAC. ${ }^{52}$

Alcaftadine $0.25 \%$ and olopatadine $0.1 \%$ demonstrated statistically significant lower mean scores in each secondary endpoint category when compared to the placebo. Statistical comparisons for secondary endpoints were made at the alpha (two-sided) $5 \%(P=0.05)$ level. Alcaftadine $0.25 \%$ also consistently demonstrated lower or equal mean scores when compared to olopatadine $0.1 \% .^{52}$

The study data exhibited alcaftadine $0.25 \%$ ophthalmic solution performed most effectively in preventing both the signs and symptoms of allergic conjunctivitis than the other alcaftadine concentrations tested. Alcaftadine $0.25 \%$ was effective in reducing conjunctival redness at the onset (CAC at 15 minutes) and prolonged duration of action (16 hours after medication instillation), suggesting a once-daily dosing 
regimen. It is of note that olopatadine $0.2 \%$ would have been an optimal active control due to its once-daily dosing but it was not available when the study was conducted. Also, the alcaftadine $0.25 \%$ and vehicle placebo formulations utilized in this study were not the final formulations currently used in the commercial product. ${ }^{52}$

\section{Clinical studies: alcafatadine $0.25 \%$, olopatadine $0.2 \%$, and placebo}

Ackerman et al later conducted a study evaluating the efficacy and duration of action of once-daily dosing with alcaftadine $0.25 \%$ and olopatadine $0.2 \%$ as compared with a placebo in the prevention of ocular itching. Additionally, the efficacy of alcaftadine $0.25 \%$ was directly compared to olopatadine $0.2 \%$ in the prevention of ocular itching associated with allergic conjunctivitis utilizing the aforementioned CAC model. ${ }^{62}$ A multicenter, double-masked, randomized, active-, placebocontrolled clinical trial was conducted $\sim 5$ weeks. Inclusion criteria were similar to the Torkildsen and Shedden study. ${ }^{28}$ Subjects also agreed to avoid disallowed medications and contact lens wear during the study period. Females who were pregnant, planning a pregnancy, lactating, or not using a medically accepted form of birth control were excluded from the study due to the category $\mathrm{C}$ labeling of olopatadine $0.2 \%$ utilized in one treatment arm. Participants were $\geq 10$ years of age. One hundred twenty-seven subjects were equally randomized into one of the three groups: alcaftadine $0.25 \%$ ophthalmic solution, olopatadine $0.2 \%$ ophthalmic solution, or placebo with 115 subjects completing the study. ${ }^{62}$

Mean ocular itching was the single primary endpoint in this study. Secondary endpoints - conjunctival redness, chemosis, lid swelling, and tearing - were also measured. An allergen challenge was performed during visit 1 in which subjects received bilateral ocular instillation of antigen followed by subject-reported itch 10 minutes after administration. The same scoring criteria utilized by Torkildsen and Shedden, and described above, were employed in this study. ${ }^{28}$ Allergen concentrations were then titrated until the subjects reported $\geq 2$ and conjunctival redness was graded by investigators at $\geq 2$. An allergen challenge was performed at visit 2 for baseline data and subjects scored their ocular itching at 3 minutes, 5 minutes, and 7 minutes. Secondary endpoints were assessed at 7 minutes, 15 minutes, and 20 minutes after allergen instillation. Subjects who met the screening criteria of $\geq 2$ for both ocular itching and conjunctival redness continued on to the third visit. Subjects were randomized at visit $3 \mathrm{a}$ and received one drop bilaterally of masked treatment. Visit $3 \mathrm{~b}$ consisted of an allergen challenge 16 hours after the drop administration. Ocular itching was subjectively graded at 3 minutes, 5 minutes, and 7 minutes after the allergen was introduced. Secondary endpoints were assessed at 7 minutes, 15 minutes, and 20 minutes. Investigators evaluated conjunctival, ciliary, and episcleral redness in addition to chemosis, whereas subjects reported lid swelling and tearing scores. Visit 4 a occurred 14 days ( \pm 3 days) later, and masked drops were again instilled. Subjects were then challenged again at 24 hours to determine primary and secondary endpoints as previously listed. ${ }^{62}$

Predefined parameters for primary efficacy data (ocular itching) included the number of subjects in each treatment group with no itch $($ score $=0)$ and minimal itch $($ score $<1)$. Pairwise treatment comparison was performed by Fisher's exact test consisting of alcaftadine $0.25 \%$ versus placebo, alcaftadine $0.25 \%$ versus olopatadine $0.2 \%$, and olopatadine $0.2 \%$ versus placebo. Mean ocular itching (primary endpoint) at 3 minutes, 5 minutes, and 7 minutes after $\mathrm{CAC}$ at 16 hours and 24 hours was statistically superior at both time frames when comparing the active treatments versus the placebo. Alcaftadine $0.25 \%$ achieved lower itch scores at all time points when compared to olopatadine $0.2 \%$. Statistical significance was attained 3 minutes after the 16-hour CAC $(P=0.026)$ in comparing the active medications. At the same time point, a higher percentage of patients in the alcaftadine group (78\%) reported minimal itch as opposed to the olopatadine $0.2 \%$ group (46\%). At 3 minutes after the 24 -hour CAC, $71 \%$ of alcaftadine $0.25 \%$ subjects reported minimal itch, whereas $47 \%$ of olopatadine $0.2 \%$ subjects reported the same findings $(P=0.061)$. Zero itch score was also assessed with a greater number of subjects in the alcaftadine $0.25 \%$ group reporting zero itch at 3 minutes and a greater number in the olopatadine $0.2 \%$ arm had zero itch at 7 minutes after the allergen challenge. Both active medications achieved statistical significance when compared to placebo when assessing secondary endpoints. Alcaftadine $0.25 \%$ and olopatadine $0.2 \%$ performed superior to the placebo in each of the vascular beds at some time points; however, no significant difference was determined between the active medications. Both active treatments provided statistical significance in reducing lid swelling and tearing at 16 hours and 24 hours compared with placebo. Also, chemosis was less at 16-hour post-CAC with alcaftadine $0.25 \%$ and olopatadine $0.2 \%$ against placebo but only alcaftadine $0.25 \%$ demonstrated statistical significance at every time point at 24 hours. $^{62}$

This study was designed to assess duration of action at 24 hours as a previous study evaluated duration at 16 hours with results suggesting a longer duration than the time 
frame allowed. ${ }^{28}$ Additionally, it allowed for direct comparison of both once-daily antiallergic ocular formulations. While both medications were successful in preventing ocular itching at the 16 -hour CAC, alcaftadine $0.25 \%$ efficacy was most apparent in the itch scores where a greater number of scores were $\leq 1.5$, whereas the scores for olopatadine were evenly distributed between 0 and 2 . The findings in this study further support the quick onset and long duration of alcaftadine $0.25 \%$ in the prevention of signs and symptoms associated with allergic conjunctivitis. ${ }^{62}$

McLaurin et $a 1^{63}$ utilized the same study design as Ackerman et $\mathrm{al}^{62}$ with 157 subjects completing the second study. Data collected from both multicenter studies were then pooled. Findings in the second study mirrored the comparison outcomes of alcaftadine $0.25 \%$ versus olopatadine $0.2 \%$ at the 16-hour allergen challenge and in mean itch scores at all time points demonstrating repeatable results.

Olopatadine $0.7 \%$ was newly released on the market, but at this time, it has only been compared to olopatadine $0.1 \%$ and $0.2 \% .{ }^{64}$ However, we feel in the short future, a study comparing the onset of action and, more importantly, duration of action of olopatadine $0.7 \%$ and alcaftadine $0.25 \%$ will be conducted.

\section{Dosage, administration, and adverse effects}

Alcaftadine has an onset of action within 15 minutes and therapeutic effect that lasts up to 24 hours. ${ }^{2,62}$ It is available in $0.25 \%$ from Allergan, Inc. (Irvine, CA, USA) and is formulated as a sterile ophthalmic solution containing $2.5 \mathrm{mg} / \mathrm{mL}$ alcaftadine and preserved with $0.005 \%$ benzalkonium chloride. It has a $\mathrm{pH} \sim 7$ and an osmolality $\sim 290 \mathrm{mOsm} / \mathrm{kg} .{ }^{59}$ Alcaftadine is dosed once per day in each eye for the prevention of itching associated with allergic conjunctivitis in individuals beginning at 2 years of age. Due to its preservative, soft contact lens wear is not recommended while instilling the drop. Reinsertion of contact lenses is suggested 10 minutes after drop administration. Alcaftadine is a well-tolerated antiallergy medication that is dosed once a day. It has a pregnancy category $\mathrm{B}$ rating in the USA and is approved for patients aged $\geq 2$ years. Adverse effects were reported in $4 \%$ of patients, including ocular symptoms, such as irritation, pruritus, hyperemia, and burning sensation upon instillation. ${ }^{2}$ Table 1 compares the antiallergic ocular medications currently available in the United States.

\section{Conclusion}

Ocular allergic reactions are dependent on the allergen load on the ocular surface, the stability of the mast cells, and the integrity of the conjunctival epithelial cells. ${ }^{28}$ Most allergens can secrete proteolytic enzymes that enhance disruption of the epithelial barrier function via degradation of tight junction proteins, which in turn facilitates the access of allergens to the conjunctival stroma. ${ }^{10,28}$ Moreover, eosinophils could be recruited to the conjunctiva of patients with allergic conjunctivitis via $\mathrm{H} 4$ receptor interaction. The eosinophils that are recruited degranulate to release mediators that destabilize the barrier function of the conjunctival epithelium. ${ }^{10}$ However, preclinical studies have shown that alcaftadine can inhibit eosinophil recruitment and allergen-induced degradation of tight junction proteins as well as promote stability of the tight junction proteins of the conjunctival epithelium. ${ }^{28,62}$ The ability of alcaftadine to inhibit the influx of eosinophils could possibly explain why alcaftadine prevents disruption of the tight junction proteins. ${ }^{10}$ Activation of $\mathrm{H} 1$ and $\mathrm{H} 2$ receptors result in itching sensation, conjunctival injection, upregulation of adhesion molecules, cytokine release, vasopermeability, collagen synthesis, and proliferation of conjunctival fibroblasts. $\mathrm{H} 4$ receptor activation is associated with the release of cytokines and chemokines, upregulation of adhesion molecules, and activation and recruitment of immune cells. ${ }^{65}$ It is of note that the histamine released following mast

Table I Ocular multiple-action antiallergy medications for use in the treatment of allergic conjunctivitis

\begin{tabular}{|c|c|c|c|c|c|}
\hline Medication, generic (brand) & Solution strength (\%) & Volume $(\mathrm{mL})$ & Daily dosage & Pregnancy category & Status \\
\hline Alcaftadine (Lastacaft) & 0.25 & 3 & I drop daily & B & $\mathrm{Rx}$ \\
\hline Azelastine hydrochloride (Optivar) & 0.05 & 6 & I drop twice daily & C & $\mathrm{Rx}$ \\
\hline Bepotastine besilate (Bepreve) & 1.5 & $2.5,5$, and 10 & I drop twice daily & $\mathrm{C}$ & $\mathrm{Rx}$ \\
\hline Epinastine hydrochloride (Elestat) & 0.05 & 5 & I drop twice daily & C & $\mathrm{Rx}$ \\
\hline Ketotifen fumarate (Zaditor) & 0.025 & 5 & I drop twice daily & C & отс \\
\hline Ketotifen fumarate (Alaway) & 0.025 & 10 & I drop twice daily & C & отс \\
\hline Olopatadine hydrochloride (Patanol) & 0.1 & 5 & I drop twice daily & C & $\mathrm{Rx}$ \\
\hline Olopatadine hydrochloride (Pataday) & 0.2 & 2.5 & I drop daily & C & $\mathrm{Rx}$ \\
\hline Olopatadine hydrochloride (Pazeo) & 0.7 & 2.5 & I drop daily & C & $\mathrm{Rx}$ \\
\hline
\end{tabular}

Notes: All listed medications contain benzalkonium chloride as a preservative. Data from studies. ${ }^{2,4,9,53,58,64}$

Abbreviations: OTC, over-the-counter; Rx, prescription. 
cell degranulation recruits and activates DCs that induce Th2lymphocyte-mediated conjunctival inflammation. However, it has been demonstrated that alcaftadine has $\mathrm{H} 4$ receptor inverse agonist activity, which in turn could inhibit H4 receptor-mediated Th2-lymphocyte-driven allergic response on the conjunctiva. ${ }^{29,32,36}$ Because activation of $\mathrm{H} 1$ and $\mathrm{H} 4$ receptors are associated with Th2-lymphocyte-driven allergen-induced inflammation of the conjunctiva, antiallergic therapeutic agents with inverse agonist activity on H1 and $\mathrm{H} 4$ receptors could provide therapeutic benefits to patients with allergic conjunctivitis. ${ }^{35,48}$ Additionally, reducing the activation and migration of allergen-bearing DCs to regional lymph nodes via $\mathrm{H} 4$ receptor inverse agonism is associated with dampening of Th2-dependent conjunctival inflammation and pruritus. ${ }^{66}$ Alcaftadine with its inverses agonist effect on $\mathrm{H} 1, \mathrm{H} 2$, and $\mathrm{H} 4$ receptors is effective at preventing histamine from binding to its receptors on vascular endothelial cells, conjunctival nerve fibers, conjunctival goblet cells, eosinophils, DCs, mast cells, and conjunctival epithelium. ${ }^{2}$ Alcaftadine is an ideal antihistamine with higher $\mathrm{H} 1$ receptor inverse agonist activity with little or no antimuscarinic activity. The antihistaminic effect of alcaftadine like most ocular antihistamines is dependent on the binding affinity for the respective histamine receptor, the duration of the binding of alcaftadine to the histamine receptor, and the speed of the alcaftadine-histamine receptor interaction. ${ }^{53}$ As such, alcaftadine is an efficacious multiple action antiallergy agent that has inverse histamine receptor agonist, anti-inflammatory, and mast cell stability effects. ${ }^{2}$

\section{Disclosure}

The authors report no financial or other conflicts of interest in this work.

\section{References}

1. Chigbu DI. The pathophysiology of ocular allergy: a review. Cont Lens Anterior Eye. 2009;32(1):3-15. [quiz 43-4].

2. Wong AH, Barg SS, Leung AK. Seasonal and perennial allergic conjunctivitis. Recent Pat Inflamm Allergy Drug Discov. 2014;8(2):139-153.

3. Mantelli F, Calder VL, Bonini S. The anti-inflammatory effects of therapies for ocular allergy. J Ocul Pharmacol Ther. 2013;29(9):786-793.

4. Mishra GP, Tamboli V, Jwala J, Mitra AK. Recent patents and emerging therapeutics in the treatment of allergic conjunctivitis. Recent Pat Inflamm Allergy Drug Discov. 2011;5(1):26-36.

5. Leonardi A. Allergy and allergic mediators in tears. Exp Eye Res. 2013; 117:106-117.

6. Chigbu DI, Sandrasekaramudaly-Brown S. Ocular surface disease: a case of vernal keratoconjunctivitis. Cont Lens Anterior Eye. 2011;34(1):39-44.

7. Mimura T, Yamagami S, Kamei Y, Goto M, Matsubara M. Specific IgE in tear fluid and features of allergic conjunctivitis. Curr Eye Res. 2013; 38(9):917-925.

8. Nye M, Rudner S, Bielory L. Emerging therapies in allergic conjunctivitis and dry eye syndrome. Expert Opin Pharmacother. 2013;14(11): 1449-1465.
9. Ridolo E, Montagni M, Caminati M, Senna G, Incorvaia C, Canonica GW. Emerging drugs for allergic conjunctivitis. Expert Opin Emerg Drugs. 2014;19(2):291-302.

10. Ono SJ, Lane K. Comparison of effects of alcaftadine and olopatadine on conjunctival epithelium and eosinophil recruitment in a murine model of allergic conjunctivitis. Drug Des Devel Ther. 2011;5:77-84.

11. Chigbu DI. Structure, function and immunology of the ocular surface. Allergic Disorders of the Ocular Surface. New York: Nova Science Publishers, Inc; 2013:7-18.

12. Forrester JV, Xu H, Kuffova L, Dick AD, McMenamin PG. Dendritic cell physiology and function in the eye. Immunol Rev. 2010;234(1):282-304.

13. Galicia-Carreon J, Santacruz C, Hong E, Jimenez-Martinez MC. The ocular surface: from physiology to the ocular allergic diseases. Rev Alerg Mex. 2013;60(4):172-183.

14. Donshik P, Ehlers W, Ballow M. Giant papillary conjunctivitis. Immunol Allergy Clin North Am. 2008;28(1):83-103,vi.

15. Elhers W, Donshik P. Giant papillary conjunctivitis. Curr Opin Allergy Clin Immunol. 2008;8(5):445-449.

16. Donshik P. Giant papillary conjunctivitis. Trans Am Ophthalmol Soc. 1994;92:687-744.

17. Knop E, Knop N. Anatomy and immunology of the ocular surface. Chem Immunol Allergy. 2007;92:36-49.

18. Irkeç M, Bozkurt B. Epithelial cells in ocular allergy. Curr Allergy Asthma Rep. 2003;3(4):352-357.

19. Pflugfelder S, Stern M. Immunoregulation on the ocular surface: 2 nd Cullen Symposium. Ocul Surf. 2009;7(2):67-77.

20. Gilger BC. Immunology of the ocular surface. Vet Clin North Am Small Anim Pract. 2008;38(2):223-231,v.

21. Paulsen F. Functional anatomy and immunological interactions of ocular surface and adnexa. Dev Ophthalmol. 2008;41:21-35.

22. Irani AM. Ocular mast cells and mediators. Immunol Allergy Clin North Am. 2008;28(1):25-42,v.

23. Bonini S, Micera A, Iovieno A, Lambiase A. Expression of Tolllike receptors in healthy and allergic conjunctiva. Ophthalmology. 2005;112(9):1528. [discussion 1529-1548].

24. Redfern RL, McDermott AM. Toll-like receptors in ocular surface disease. Exp Eye Res. 2010;90(6):679-687.

25. Micera A, Stampachiacchiere B, Aronni S, dos Santos M, Lambiase A. Toll-like receptors and the eye. Curr Opin Allergy Clin Immunol. 2005; 5(5):451-458.

26. Mergler S, Garreis F, Sahlmüller M, et al. Calcium regulation by thermo- and osmosensing transient receptor potential vanilloid channels (TRPVs) in human conjunctival epithelial cells. Histochem Cell Biol. 2012;137(6):743-761.

27. Kaneko Y, Szallasi A. Transient receptor potential (TRP) channels: a clinical perspective. Br J Pharmacol. 2014;171(10):2474-2507.

28. Torkildsen G, Shedden A. The safety and efficacy of alcaftadine $0.25 \%$ ophthalmic solution for the prevention of itching associated with allergic conjunctivitis. Curr Med Res Opin. 2011;27(3):623-631.

29. Amaral MM, Davio C, Ceballos A, et al. Histamine improves antigen uptake and cross-presentation by dendritic cells. J Immunol. 2007; 179(6):3425-3433.

30. Saravanan C, Bharti SK, Jaggi S, Singh SK. Histamine H(4) receptor: a novel target for inflammation therapy. Mini Rev Med Chem. 2011; 11(2):143-158.

31. Damaj BB, Becerra CB, Esber HJ, Wen Y, Maghazachi AA. Functional expression of $\mathrm{H} 4$ histamine receptor in human natural killer cells, monocytes, and dendritic cells. J Immunol. 2007;179(11):7907-7915.

32. Smuda C, Bryce PJ. New developments in the use of histamine and histamine receptors. Curr Allergy Asthma Rep. 2011;11(2):94-100.

33. Bhatt HG, Agrawal YK, Raval HG, Manna K, Desai PR. Histamine H4 receptor: a novel therapeutic target for immune and allergic responses. Mini Rev Med Chem. 2010;10(14):1293-1308.

34. Criado PR, Criado RF, Maruta CW, Machado Filho C. Histamine, histamine receptors and antihistamines: new concepts. An Bras Dermatol. 2010;85(2):195-210. 
35. Marson CM. Targeting the histamine H4 receptor. Chem Rev. 2011; 111(11):7121-7156.

36. Kmiecik T, Otocka-Kmiecik A, Gorska-Ciebiada M, Ciebiada M. Tlymphocytes as a target of histamine action. Arch Med Sci. 2012;8(1):154-161.

37. Imamachi N, Park GH, Lee H, et al. TRPV1-expressing primary afferents generate behavioral responses to pruritogens via multiple mechanisms. Proc Natl Acad Sci U S A. 2009;106(27):11330-11335.

38. Ohbayashi M, Manzouri B, Morohoshi K, Fukuda K, Ono SJ. The role of histamine in ocular allergy. Adv Exp Med Biol. 2010;709:43-52.

39. Abbas AK, Lichtman AHH, Pillai S. Allergy. Cellular and Molecular Immunology. Philadelphia: Elsevier Saunders; 2015:239-264.

40. Butrus S, Portela R. Ocular allergy: diagnosis and treatment. Ophthalmol Clin North Am. 2005;18(4):485-492,v.

41. Chigbu DI. Immunology relevant to allergic ocular surface diseases. Allergic Disorders of the Ocular Surface. New York: Nova Science Publishers, Inc; 2013:53-74.

42. Zheng X, Ma P, de Paiva CS, et al. TSLP and downstream molecules in experimental mouse allergic conjunctivitis. Invest Ophthalmol Vis Sci. 2010;51(6):3076-3082.

43. Takai T. TSLP expression: cellular sources, triggers, and regulatory mechanisms. Allergol Int. 2012;61(1):3-17.

44. Deng R, Su Z, Lu F, et al. A potential link between bacterial pathogens and allergic conjunctivitis by dendritic cells. Exp Eye Res. 2014; 120:118-126.

45. Wilson SR, Thé L, Batia LM, et al. The epithelial cell-derived atopic dermatitis cytokine TSLP activates neurons to induce itch. Cell. 2013;155(2):285-295.

46. Broide DH. Immunomodulation of allergic disease. Annu Rev Med. 2009;60:279-291.

47. Abelson MB, Smith L, Chapin M. Ocular allergic disease: mechanisms, disease sub-types, treatment. Ocul Surf. 2003;1(3):127-149.

48. Leonardi A, Di Stefano A, Vicari C, Motterle L, Brun P. Histamine $\mathrm{H} 4$ receptors in normal conjunctiva and in vernal keratoconjunctivitis. Allergy. 2011;66(10):1360-1366.

49. Brown J, Wilson T, Metcalfe D. The mast cell and allergic diseases: role in pathogenesis and implications for therapy. Clin Exp Allergy. 2008;38(1):4-18.

50. Shim WS, Tak MH, Lee MH, et al. TRPV1 mediates histamine-induced itching via the activation of phospholipase A2 and 12-lipoxygenase. J Neurosci. 2007;27(9):2331-2337.

51. Chigbu DI. The management of allergic eye diseases in primary eye care. Cont Lens Anterior Eye. 2009;32(6):260-272.

52. Greiner JV, Edwards-Swanson K, Ingerman A. Evaluation of alcaftadine $0.25 \%$ ophthalmic solution in acute allergic conjunctivitis at 15 minutes and 16 hours after instillation versus placebo and olopatadine $0.1 \%$. Clin Ophthalmol. 2011;5:87-93.
53. Wade L, Bielory L, Rudner S. Ophthalmic antihistamines and H1-H4 receptors. Curr Opin Allergy Clin Immunol. 2012;12(5):510-516.

54. Namdar R, Valdez C. Alcaftadine: a topical antihistamine for use in allergic conjunctivitis. Drugs Today (Barc). 2011;47(12):883-890.

55. Bohets H, McGowan C, Mannens G, Schroeder N, Edwards-Swanson K, Shapiro A. Clinical pharmacology of alcaftadine, a novel antihistamine for the prevention of allergic conjunctivitis. J Ocul Pharmacol Ther. 2011;27(2):187-195.

56. Lin JH, Yamazaki M. Role of P-glycoprotein in pharmacokinetics: clinical implications. Clin Pharmacokinet. 2003;42(1):59-98.

57. Lin JH, Lu AY. Interindividual variability in inhibition and induction of cytochrome P450 enzymes. Annu Rev Pharmacol Toxicol. 2001;41: $535-567$.

58. Mahvan TD, Buckley WA, Hornecker JR. Alcaftadine for the prevention of itching associated with allergic conjunctivitis. Ann Pharmacother. 2012;46(7-8):1025-1032.

59. Zhang Y. Alcaftadine Clinical Pharmacology Review, NDA 22-134. Food and Drug Administration. Available from: http:www.fda.gov/downloads/ Drugs/DevelopmentApprovalProcess/DevelopmentResources/ UCM223817.pdf. Accessed July 24, 2014.

60. Abelson MB, Loeffler O. Conjunctival allergen challenge: models in the investigation of ocular allergy. Curr Allergy Asthma Rep. 2003; 3(4):363-368.

61. Abelson MB, Chambers WA, Smith LM. Conjunctival allergen challenge. A clinical approach to studying allergic conjunctivitis. Arch Ophthalmol. 1990;108(1):84-88.

62. Ackerman S, D’Ambrosio F Jr, Greiner JV, Villanueva L, Ciolino JB, Hollander DA. A multicenter evaluation of the efficacy and duration of action of alcaftadine $0.25 \%$ and olopatadine $0.2 \%$ in the conjunctival allergen challenge model. J Asthma Allergy. 2013;6:43-52.

63. McLaurin EB, Marsico NP, Ackerman SL, et al. Ocular itch relief with alcaftadine $0.25 \%$ versus olopatadine $0.2 \%$ in allergic conjunctivitis: pooled analysis of two multicenter randomized clinical trials. Adv Ther. 2014;31(10):1059-1071.

64. Chambers WA. Clinical Review of NDA 206276. Food and Drug Administration. Available from: http://www.fda.gov/downloads/Drugs/ DevelopmentApprovalProcess/DevelopmentResources/UCM434580. pdf. Accessed May 30, 2015.

65. Abelson MB, Shetty S, Korchak M, Butrus SI, Smith LM. Advances in pharmacotherapy for allergic conjunctivitis. Expert Opin Pharmacother. 2015;16(8):1219-1231.

66. Cowden JM, Zhang M, Dunford PJ, Thurmond RL. The histamine H4 receptor mediates inflammation and pruritus in Th2-dependent dermal inflammation. J Invest Dermatol. 2010;130(4):1023-1033.
Clinical Ophthalmology

\section{Publish your work in this journal}

Clinical Ophthalmology is an international, peer-reviewed journal covering all subspecialties within ophthalmology. Key topics include: Optometry; Visual science; Pharmacology and drug therapy in eye diseases; Basic Sciences; Primary and Secondary eye care; Patien Safety and Quality of Care Improvements. This journal is indexed on Submit your manuscript here: http://www.dovepress.com/clinical-ophthalmology-journal

\section{Dovepress}

PubMed Central and CAS, and is the official journal of The Society of Clinical Ophthalmology (SCO). The manuscript management system is completely online and includes a very quick and fair peer-review system, which is all easy to use. Visit http://www.dovepress.com/ testimonials.php to read real quotes from published authors. 